\title{
Influence of Watershed Scale Atrazine Reduction Practices on Pesticides and Fishes within Channelized Agricultural Head- water Streams
}

\author{
Peter C. Smiley Jr. ${ }^{*}$, Kevin W. King ${ }^{1}$, Robert B. Gillespie ${ }^{2}$, and Norman R. Fausey ${ }^{1}$ \\ ${ }^{1}$ USDA-ARS Soil Drainage Research Unit, 590 Woody Hayes Drive, Columbus, Ohio 43210, USA; ${ }^{2}$ Depart- \\ ment of Biology, Indiana University-Purdue University Fort Wayne, Fort Wayne, Indiana 46805, USA
}

Received: November 28, 2011 / Accepted: February 28, 2012

\begin{abstract}
Application of pesticides within the watersheds of agricultural streams typically leads to increased instream pesticide concentrations that reduces water quality and threatens aquatic life. Pesticide reduction practices that reduce pesticide application within agricultural watersheds should reduce concentrations of pesticides within agricultural streams. Unforfunately, the influence of pesticide reduction practices on pesticides and the biota within agricultural headwater streams has not been empirically evaluated. We evaluated the watershed scale influence of atrazine reduction practices on pesticides, pesticide mixtures, and fish communities within channelized agricultural headwater streams in central Ohio. Water samples for pesticide measurements and fishes were collected in the spring and summer from a treatment stream (watershed size - $3.89 \mathbf{k m}^{2}$ ) that received atrazine reduction practices within 26 to $31 \%$ of its watershed during the first two years and then the watershed usage of these practices was reduced to less than $6 \%$ in the last four years. We also collected water samples and fishes during the same time from a control stream (watershed size $4.54 \mathrm{~km}^{2}$ ) that received atrazine reduction practices in $6 \%$ or less of its watershed during the study. Only three of 15 pesticide response variables and two of 15 fish community response variables indicated a potential effect of atrazine reduction practices. Mean differences in atrazine desethyl concentration, atrazine desethyl percent occurrence, and the number of pesticides between the control and treatment streams were greater during the time period with atrazine reduction practices than the time period without atrazine reduction practices. Mean differences
\end{abstract}

* Corresponding author: rocky.smiley@ars-usda.gov in trophic guild richness and fish species composition similarity between the control and treatment streams occurred between time periods with and without atrazine reduction practices only during the summer. Our results suggest that implementing atrazine reduction practices to reduce atrazine usage within small portions ( $30 \%$ or less) of the watersheds of channelized agricultural headwater streams may not influence pesticides, pesticide mixtures, and fish community structure during the spring and summer.

Keywords: Herbicides, fungicides, hazard indexes, fishes, headwater streams.

\section{Introduction}

Agricultural pesticides (i.e., insecticides, herbicides, and fungicides) represent a threat to drinking water quality and aquatic life within agricultural streams. Many agricultural streams serve as source waters for urban drinking water supplies within the Midwestern United States. Transport of pesticides from upstream agricultural streams to downstream drinking water supplies can result in an increase in pesticide concentrations in raw and finished tap water that exceed the established drinking water standards to protect human health (Brian, 1995; Coupe and Blomquist, 2004). Pesticide risks to aquatic life in agricultural streams are greater than risks to human health because agricultural streams routinely exceed benchmark levels established to protect aquatic life (Gilliom, 2007). Excessive pes- 
ticide concentrations often lead to death of stream organisms and subsequently alter stream population and community characteristics (Hunt et al., 2006). Even low levels of pesticide concentrations may lead to sublethal effects involving changes to physiology, morphology, and behavior of individual stream organisms (Crawford, 2001; Dabrowski et al., 2002; Maltby and Hills, 2008). Despite these environmental risks pesticide usage continues within the watersheds of agricultural streams because effective pest control is critical for maintaining agricultural productivity. Development of sustainable pesticide use strategies and practices are needed to ensure future agricultural productivity and reduce the environmental impacts of pesticide usage on agricultural streams.

Integrated pest management (IPM) strategies that consider the interests and impacts of pest management on producers, society, and the environment represent one possible solution for reducing the impacts of pesticides on agricultural streams. Development of IPM and its early adoption in the United States stemmed in part from a desire to reduce the environmental risks related to pesticide usage (Kogan, 1998). Typical descriptions of IPM strategies focus on insect pests, but weeds are also agricultural pests from an IPM perspective (Kogan, 1998). IPM approaches implemented by the Natural Resources Conservation Service (NRCS) in the United States consist of a range of individual pest management practices involving the prevention, avoidance, suppression, and monitoring of pests (NRCS, 2010). Farmer adoption of comprehensive IPM strategies has been weak, but farmers have exhibited a willingness to implement individual pest management practices (Hammond et al., 2006). Individual pest management practices have been applied on a wide range of crop types throughout the United States. Usage of individual pest management practices differs among crop types, but typically include crop rotations and scouting for pests (USDA NASS, 2000).

Logically and intuitively, pesticide reduction practices and conservation practices that result in less pesticide application on agricultural fields should lead to reduced concentrations of associated pesticides within agricultural streams. Reduced pesticide application should be particularly effective in reducing pesticide concentrations within agricultural streams having tile-drained watersheds that enable agricultural runoff to bypass riparian zones and wetlands that might dissipate pesticides (Smiley et al., 2011 ). Small plot scale studies and watershed modeling analyses are supportive of this logical conclusion, but the impacts of pesticide reduction practices and other conservation practices at the watershed scale has not been quantified. Plot scale studies as a result of their small spatial and temporal scale are not representative of watershed scale effects. Watershed modeling analyses simply predict the effects of different practices or management scenarios instead of actually documenting the watershed scale effects. Thus, field studies documenting watershed responses to pesticide reduction practices and other agricultural conservation practices are critically needed to identify effective practices capable of reducing the impacts of agriculture on agricultural streams.

Only a limited number of field studies examining the influence of pesticide reduction practices at the watershed scale have been conducted (Kerr and Chung, 2001; Reichenberger et al., 2007; Kay et al., 2009; Table 1). Watershed scale studies examining correlations between pesticide usage and pesticide concentrations in streams have found that increasing or decreasing trends in pesticide usage are correlated with corresponding changes in concentrations within the streams (Table 1). This finding suggests that pesticide reduction practices that reduce the amounts of pesticides applied within the watershed should reduce pesticide concentrations within streams. Conflicting results have been observed in studies that attempted to determine the influence of specific pesticide reduction practices or conservation practices. Atrazine concentrations and occurrence did not decrease in an lowa stream that modified $19 \%$ of its watershed land use by converting agricultural fields to prairie, adopting no-till tillage, and eliminating pre-emergence herbicide applications (Schilling and Thompson, 2000). Additionally, implementation of a combination of agricultural conservation practices (i.e., mostly grassed waterways, terraces, and removal of cropland via Conservation Reserve Program) within 15\% of a Missouri watershed did not reduce concentrations of atrazine or other commonly applied herbicides (Lerch et al., 2011 a; Lerch et al., $2011 \mathrm{~b})$. Perhaps the conflicting results can simply be explained by the small percentages of the watershed area that implements pesticide reduction practices. However, uncertainty remains regarding the effectiveness of pesticide reduction practices because so few watershed scale assessments have been conducted. The ecological benefits of reducing pesticide concentrations are also relatively unknown because most previous watershed scale assessments have not evaluated ecological responses (Table 1). Laboratory bioassays conducted to determine the toxicity of the water collected from a California stream found that increasing pesticide concentrations and increasing the proximity of pesticide applications to the sampling sites was correlated with increasing invertebrate mortality (Hunt et al., 2006). There is a critical need to determine if pesticide reduction practices lead to reduced impacts on aquatic life in streams.

We measured pesticide (i.e., herbicides and fungicides) concentrations and sampled fishes within one channelized headwater agricultural stream that was not subjected to atrazine reduction practices and one channelized headwater agricultural stream that was treated with atrazine reduction practices in the first two years of the study, but not in the last four years. Atrazine reduction practices applied in the treatment watershed during the first two years included a combination of the following practices: 1) use an alternative herbicide other than atrazine; 2) planting of wheat or another small grain instead of corn; 3) use a reduced rate of atrazine with post emergent application; 4) use a reduced rate of atrazine with incorporation into the soil; and 5) use a reduced rate of atrazine without limitations on the timing of application or use of incorporation. We then compared the difference in pesticide concentrations, pesticide occurrences, pesticide mixtures, hazard indexes, and fish community response variables before and after implementation of atrazine reduction practices. Specifically, we addressed the following hypotheses: 1) atrazine reduction practices implemented within channelized agricultural headwater streams will reduce the concentrations and occurrence of atrazine and its metabolite atra- 
Table 1. Summary of characteristics and findings from watershed scale studies describing effects and/or potential effects of pesticide reduction practices on agricultural streams.

\begin{tabular}{|c|c|c|c|c|}
\hline Citation & Location & Intent & $\begin{array}{c}\text { \# and Type of } \\
\text { Response Variables }\end{array}$ & Findings \\
\hline Matthiessen et al. 1992 & United Kingdom & $\begin{array}{l}\text { Examine concentrations of herbicides } \\
\text { in soil, subsurface drains, and stream } \\
\text { before and after herbicide } \\
\text { application }\end{array}$ & 4 herbicides & $\begin{array}{l}\text { Herbicide concentrations increase within stream following } \\
\text { rainfall. Instream herbicide concentrations dependent on } \\
\text { combination of time since application, timing of first subsequent } \\
\text { rainfall, and herbicide degradation rate. }\end{array}$ \\
\hline Williams etal. 1995 & United Kingdom & $\begin{array}{l}\text { Understand factors influencing } \\
\text { pesticide runoff and to provide data } \\
\text { for calibration of predictive models }\end{array}$ & $\begin{array}{l}4 \text { herbicides } \\
3 \text { insecticides }\end{array}$ & $\begin{array}{l}\text { After herbicide application pesticides concentrations in streams } \\
\text { increases following rainfall event. Increased instream pesticide } \\
\text { concentrations influenced by rainfall, timing of pesticide } \\
\text { application, and soil properties. }\end{array}$ \\
\hline Kreuger 1998 & Sweden & $\begin{array}{l}\text { Examine loss of pesticides from } \\
\text { agricultural watershed }\end{array}$ & $\begin{array}{l}35 \text { herbicides } \\
4 \text { fungicides } \\
11 \text { insecticides }\end{array}$ & $\begin{array}{l}\text { Increasing herbicide usage correlated with increasing occurrence } \\
\text { of herbicides in streams. Atypical peaks in herbicide } \\
\text { concentrations a result of spillage and/or cleaning of spraying } \\
\text { equipment. }\end{array}$ \\
\hline Jaynes et al. 1999 & lowa & $\begin{array}{l}\text { Measure impact of farming on surface } \\
\text { water quality }\end{array}$ & 4 herbicides & $\begin{array}{l}\text { Increased herbicide concentrations during atypical periods a } \\
\text { result of equipment cleaning. }\end{array}$ \\
\hline $\begin{array}{l}\text { Schilling and Thompson } \\
2000\end{array}$ & lowa & $\begin{array}{l}\text { Evaluate influence of land use } \\
\text { conversion and improved agricultural } \\
\text { management }\end{array}$ & $\begin{array}{l}3 \text { herbicides } \\
1 \text { herbicide } \\
\text { metabolite }\end{array}$ & $\begin{array}{l}\text { Conversion of } 19 \% \text { of the watershed from agricultural land use } \\
\text { to prairie, implementation of no-till tillage, and eliminating pre- } \\
\text { emergent herbicide applications had no effect on atrazine } \\
\text { concentrations and load. }\end{array}$ \\
\hline Scribner et al. 2000 & $\begin{array}{l}\text { Midwestern } \\
\text { United States }\end{array}$ & $\begin{array}{l}\text { Determine if changes in herbicide use } \\
\text { resulted in changes in herbicide } \\
\text { concentrations within streams }\end{array}$ & $\begin{array}{l}8 \text { herbicides } \\
4 \text { herbicide } \\
\text { metabolites }\end{array}$ & $\begin{array}{l}\text { Percent occurrence was not influenced by herbicide usage. } \\
\text { Concentrations of herbicides that exhibited }>50 \% \text { decrease in } \\
\text { use decreased in concentrations. Concentrations of herbicides } \\
\text { that did not differ in usage did not change } \\
\text {. }\end{array}$ \\
\hline Crawford 2001 & Indiana & $\begin{array}{l}\text { Examine trends in water quality to } \\
\text { understand the natural and human } \\
\text { factors that affect water quality }\end{array}$ & $\begin{array}{l}8 \text { herbicides } \\
1 \text { insecticide }\end{array}$ & $\begin{array}{l}\text { Increase pesticide usage correlated with increasing mean } \\
\text { concentrations of } 14 \text { measured pesticides. Incorporation reduces } \\
\text { pesticide concentrations. Herbicides with greater half-lives } \\
\text { found more often and in greater concentrations than those with } \\
\text { lesser half-lives }\end{array}$ \\
\hline Homes et al. 2001 & Indiana & $\begin{array}{l}\text { Evaluate potential of simple tools for } \\
\text { predicting watershed susceptibility to } \\
\text { herbicide contamination }\end{array}$ & 5 herbicides & $\begin{array}{l}\text { Herbicide application weakly correlated with alachlor, atrazine, } \\
\text { and metolachlor concentrations. }\end{array}$ \\
\hline Hyer et al. 2001 & Virginia & $\begin{array}{l}\text { Examine processes that control } \\
\text { episodic streamwater transport of } \\
\text { atrazine }\end{array}$ & 1 herbicide & $\begin{array}{l}\text { Surface runoff and soil-water transport are significant } \\
\text { mechanisms for delivering atrazine to streams during storm } \\
\text { events. Suggests that practices that reduce surface runoff would } \\
\text { decrease instream atrazine concentrations. }\end{array}$ \\
\hline
\end{tabular}

zine desethyl; 2) atrazine reduction practices implemented within channelized agricultural headwater streams will alter pesticide mixtures and their predicted toxicity for fishes; and 3) atrazine reduction practices implemented within channelized agricultural headwater streams will alter fish community structure.

\section{Materials and Methods}

\section{Study Area and Atrazine Reduction Practices}

Upper Big Walnut Creek (UBWC) is located in central Ohio (Figure 1) and is part of the Scioto River watershed. Cropland consisting of corn, soybean, or wheat is the dominant land use in the UBWC watershed. UBWC watershed is located in the humid continental, hot summer climatic region of the United States. Daily temperatures range from an average minimum of $-9.6^{\circ} \mathrm{C}$ in January to an average maximum of $33.9^{\circ} \mathrm{C}$ in July. The 30 year normal rainfall recorded near the southwest portion of the watershed was $985 \mathrm{~mm}$. Monthly distribution of rainfall exhibits a bimodal distribution with a primary peak in late spring and early summer and a secondary peak in late fall and early winter. Thunderstorms during the spring and summer produce short duration intense rainfalls. Moisture in the form of frozen precipitation or snow averages $500 \mathrm{~mm}$ annually and occurs primarily in the winter (December to March).

The majority of headwater streams in the UBWC watershed are impaired by nutrient enrichment, pathogens, and habitat degradation stemming from current agricultural management practices (Ohio EPA, 2005). Pesticides are also a critical watershed management issue within the UBWC watershed. Atrazine in particular is a contaminant of concern statewide within Ohio because of the occurrence of elevated atrazine concentrations within surface drinking water supplies (Ohio EPA, 2008; Ohio EPA, 2010). Atrazine concentrations within UBWC headwater streams and its downstream reservoir have periodically exceeded the drinking water standards (Malcolm Pirnie, 1999; Smiley and Gillespie, 2010, Smiley et al., 2010). Elevated atrazine concentrations within the reservoir prompted the implementation of a special Environmental Quality Incentives Program (EQIP) in 1999 within the UBWC that promoted the adoption of IPM (NRCS practice 595) to address water quality concerns related to atrazine.

Five atrazine reduction practices were offered as part of the special EQIP for crop areas planted to corn: 1) use an alterna- 


\begin{tabular}{|c|c|c|c|c|}
\hline Citation & Location & Intent & $\begin{array}{c}\text { \# and Type of Response } \\
\text { Variables }\end{array}$ & Findings \\
\hline Dabrowski et al. 2002 & Germany & $\begin{array}{l}\text { Evaluate influence of watershed } \\
\text { characteristics }\end{array}$ & 3 insecticides & $\begin{array}{l}\text { Watersheds with the narrowest buffers, greatest slopes, } \\
\text { and most erosion rills had the greatest pesticide } \\
\text { contamination }\end{array}$ \\
\hline Lerch and Blanchard 2003 & $\begin{array}{l}\text { Missouri and } \\
\text { lowa }\end{array}$ & $\begin{array}{l}\text { Document herbicide occurrence, } \\
\text { estimate herbicide transport, and } \\
\text { determine if herbicide transport is } \\
\text { related to watershed soil properties }\end{array}$ & $\begin{array}{c}6 \text { herbicides } \\
4 \text { herbicide metabolites }\end{array}$ & $\begin{array}{l}\text { Timing of herbicide application likely important as timing } \\
\text { of rainfall relative to herbicide application was an } \\
\text { important factor. Also, claypan soils with argillic horizons } \\
\text { increased surface runoff and atrazine loss. }\end{array}$ \\
\hline Hunt et al. 2006 & California & $\begin{array}{l}\text { Determine if geographic location of } \\
\text { pesticide application could be used } \\
\text { to direct monitoring efforts }\end{array}$ & $\begin{array}{c}11 \text { insecticides } \\
4 \text { invertebrate laboratory } \\
\text { bioassay variables }\end{array}$ & $\begin{array}{l}\text { Increased pesticide application rate correlated with } \\
\text { increasing pesticide concentrations and toxicity within } \\
\text { streams. Increasing proximity of pesticide applications } \\
\text { increases concentrations and toxicity. }\end{array}$ \\
\hline Vu et al. 2006 & Japan & $\begin{array}{l}\text { Monitor pesticide concentrations } \\
\text { and hydrology in an agricultural } \\
\text { watershed and examine key factors } \\
\text { influencing herbicide runoff for the } \\
\text { evaluation of BMPs to reduce } \\
\text { herbicides }\end{array}$ & 17 herbicides & $\begin{array}{l}\text { Maximum herbicide concentrations and loss occurs in } \\
\text { paddy fields and streams shortly after herbicide } \\
\text { application and subsequent storm events. Simulation } \\
\text { modeling predicts increasing water storage capacity and } \\
\text { water holding period of individual paddy fields will } \\
\text { decrease instream herbicide concentrations. }\end{array}$ \\
\hline Freitas et al. 2008 & Switzerland & $\begin{array}{l}\text { Determine fate of selected } \\
\text { herbicides in topsoil and transport } \\
\text { to adjacent streams after } \\
\text { application }\end{array}$ & 5 herbicides & $\begin{array}{l}\text { Herbicide application to fields with saturated soils } \\
\text { resulted in greater increases in herbicide concentrations } \\
\text { within the streams than application to fields that did not } \\
\text { have saturated soils. Suggests importance of avoiding } \\
\text { herbicide applications to certain parts of watershed } \\
\text { based on watershed hydrology }\end{array}$ \\
\hline Vecchia et al. 2009 & $\begin{array}{l}\text { Midwest } \\
\text { and Central } \\
\text { Plains States }\end{array}$ & $\begin{array}{l}\text { Assess trends in concentrations and } \\
\text { usage of commonly occurring } \\
\text { herbicides and to evaluate if trends } \\
\text { indicate potential influence of } \\
\text { agricultural practices }\end{array}$ & 4 herbicides & $\begin{array}{l}\text { Herbicides that decreased in usage also exhibited } \\
\text { decreased instream concentrations. Herbicides that did } \\
\text { not differ in usage did not exhibit changes in } \\
\text { concentrations }\end{array}$ \\
\hline Lerchet al. $2011 \mathrm{a}$ & Missouri & $\begin{array}{l}\text { Analyze trends in concentration and } \\
\text { load of selected herbicides and to } \\
\text { document influence of BMP } \\
\text { implementation }\end{array}$ & 4 herbicides & $\begin{array}{l}\text { Increases and decreases in use of selected herbicide } \\
\text { results in corresponding decreases and increases in stream } \\
\text { concentrations. Incorporation reduces herbicide } \\
\text { concentrations. Increased BMP implementation over } 15 \\
\text { year period does not influence herbicide concentrations. }\end{array}$ \\
\hline Lerch et al. $2011 \mathrm{~b}$ & Missouri & $\begin{array}{l}\text { Analyze trends in atrazine } \\
\text { concentrations and loads, evaluate } \\
\text { potential ecosystem effects of } \\
\text { atrazine, and assess key factors } \\
\text { controlling atrazine transport }\end{array}$ & 1 herbicide & $\begin{array}{l}\text { Annual atrazine loads correlated highly with vulnerability } \\
\text { index that incorporates relative timing of application, soil } \\
\text { dissipation kinetics, and occurrence of runoff events. }\end{array}$ \\
\hline
\end{tabular}

tive herbicide other than atrazine; 2 ) introduce wheat or another small grain into the rotation; 3 ) use a reduced rate of atrazine $(1.12 \mathrm{~kg} / \mathrm{ha})$ with post emergent application; 4) use a reduced rate of atrazine $(1.12 \mathrm{~kg} / \mathrm{ha})$ with incorporation into the soil; and 5) use a reduced rate of atrazine $(1.12 \mathrm{~kg} / \mathrm{ha})$ without limitations on the timing of application or use of incorporation. Atrazine reduction practices were cost-shared at rates ranging from \$12.36 per ha for reducing atrazine applications to 1.12 $\mathrm{kg} / \mathrm{ha}$ without limitations on application timing or use of incorporation to $\$ 37.06$ per ha for use of alternative herbicide or introducing a small grain into the rotation. The most popular option was the $\$ 37.06$ per hectare payment for using an alternative herbicide. Funding for voluntary adoption of these atrazine reduction practices was available on a field by field basis for up to three times during the five year contract period. The special EQIP resulted in the adoption of atrazine reduction practices on
$16 \%$ of the cropland in the UBWC. Compliance with this special EQIP program was verified by the Natural Resources Conservation Service through chemical receipt analysis.

Two channelized headwater streams (A, B) were selected and instrumented for this study (Figure 1). The dominant land use in the watershed of both streams was row-crop agriculture (Table 2). Watersheds of these streams consisted of large, systematic tile drained fields. Previous assessments of watershed characteristics confirmed that these streams were similar to each other in watershed size, watershed shape, land use, and soil types (King et al., 2008). Both streams contained narrow riparian zones consisting mostly of herbaceous riparian vegetation and exhibited the straightened, over-enlarged, trapezoidal channel shape typical of agricultural drainage ditches in the Midwestern United States (Smiley et al., 2010). Enrollment in the special EQIP for the adoption of atrazine reduction practices was 


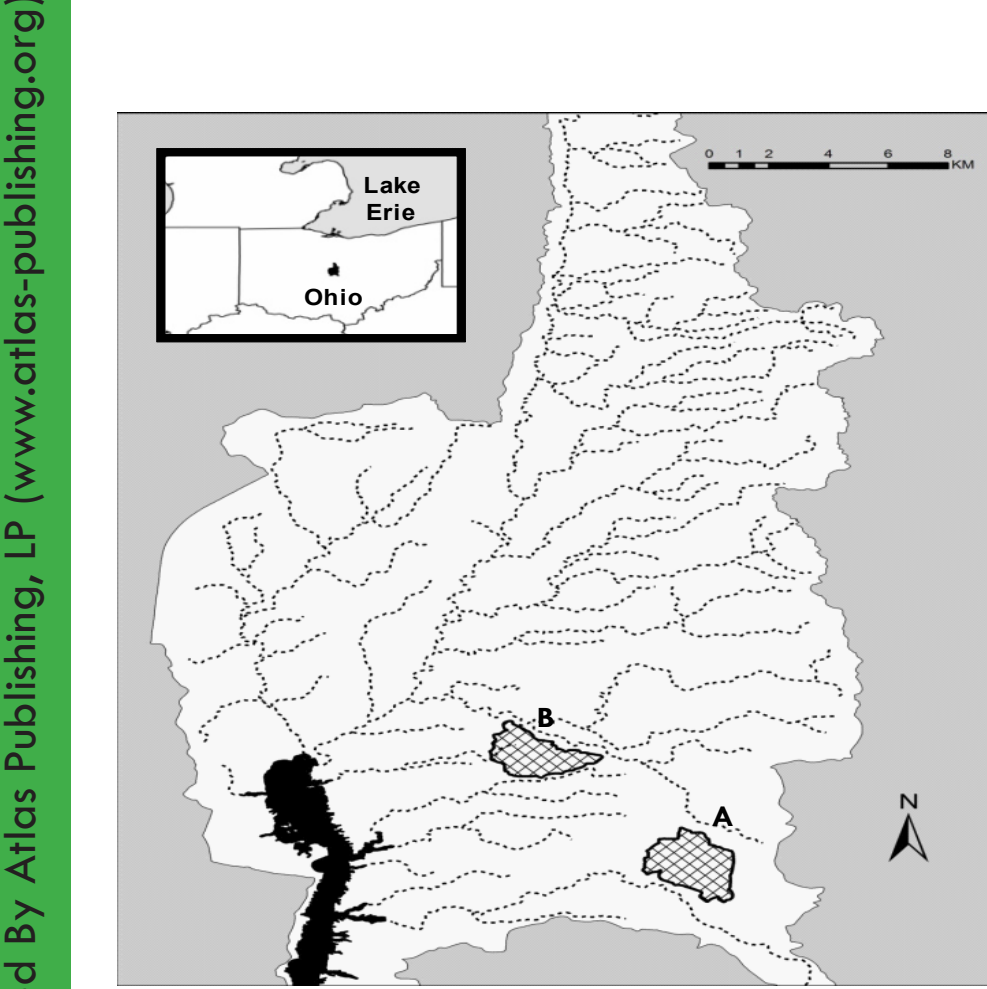

Figure 1. Location of control (A) and treatment (B) channelized agricultural headwater streams within the Upper Big Walnut Creek watershed, Ohio.

Table 2. Watershed characteristics of control stream (Figure 1, A) and treatment stream (Figure 1, B) within the Upper Big Walnut Creek watershed, Ohio.

\begin{tabular}{lcc}
\hline & Control & Treatment \\
\hline Size and Shape Characteristics & & \\
& & \\
Watershed size $\left(\mathrm{km}^{2}\right)$ & 4.54 & 3.89 \\
Relief $(\mathrm{m})$ & 15.8 & 19.2 \\
Total Channel Length $(\mathrm{m})$ & 677 & 1000 \\
Surface drainage density (m/ha) & 1.5 & 2.6 \\
Elongation (dimensionless) & 0.77 & 0.68 \\
Circularity (dimensionless) & 0.59 & 0.54
\end{tabular}

\section{Land Use Characteristics}

Percentage Agriculture

$95.3 \quad 88.9$

Percentage

$4.6 \quad 10.8$

Forested/Wetland/Scrub-Shrub

Percentage Urban

0.1

0.1

\section{Soil Characteristics}

Percentage Fine, Illitic, Mesic Aeric

47.3

52.9

Epiaquales

Percentage Fine, Mixed, Active,

Mesic Typic Argiaquolls

Percentage Fine-loamy, Mixed,

Active, Mesic Aquic Hapludalfs

Mean Bulk Density $\left(\mathrm{g} / \mathrm{cm}^{3}\right)$

Mean Water Holding Capacity

$\left(\mathrm{cm}^{3} / \mathrm{cm}^{3}\right)$

Mean Percentage Total Carbon promoted in the treatment watershed (Figure 1, B), but not the control watershed (Figure 1, A). As a result from 2004 to 2010 the percent of voluntary enrollment in the special EQIP within the control watershed was $6 \%$ of the watershed or less (Table 3 ). Conversely, the percent of voluntary enrollment in the treatment watershed ranged from 26 to $31 \%$ of the watershed from 2004 to 2006 and then decreased to less than 6\% beginning in 2007 (Table 3). This pattern of voluntary adoption between paired watershed results in a reverse before-after-control-impact (BACl) design (Green, 1979; Smiley et al., 2009) that enabled us to quantitatively evaluate the watershed scale influence of atrazine reduction practices intended to reduce atrazine use and concentrations within adjacent streams.

\section{Water Sampling and Pesticide Measurements}

Water samples were collected from March 2005 until August 2010 at the downstream outlet of the watershed of each stream. We focused our assessment of the influence of atrazine reduction practices during the spring (March to May) and summer (June to August) seasons. We anticipated that any potential effects of atrazine reduction practices would be most likely observed during these seasons that coincide with spring herbicide applications and the typical spring flush that occurs in many Midwestern United States streams following herbicide application (Thurman et al., 1991). Water samples were collected with automated water samplers. Automated water samplers were programmed to collect water samples on a $1-\mathrm{mm}$ volumetric flow depth interval in 2005 and then on a six hour time interval in subsequent years (2006 to 2010). Each week all individual water samples collected on the 1-mm volumetric flow depth or six hour time intervals were composited into one weekly sample. Periodically, additional storm water samples were collected with automated water samplers. In May 2006 we began collecting weekly grab samples to supplement our collecting efforts during periods of reduced discharge that occurs in headwater streams in the summer. We collected and analyzed 562 water samples as part of this six year study. The number of samples differed slightly among streams, seasons, and years as a result of precipitation, hydrology, and climate. We collected an average of 23 water samples (range -5 to 59 ) from each channelized stream each season.
Table 3. Percent watershed enrollment in atrazine reduction practices (NRCS practice 595) within control stream (Figure 1, A) and treatment stream (Figure 1, B) from 2004 to 2010.

\begin{tabular}{lcc}
\hline & Control & Treatment \\
\hline 2004 & 6 & 26 \\
2005 & 1 & 31 \\
2006 & 5 & 28 \\
2007 & 1 & 5 \\
2008 & 3 & 3 \\
2009 & 0 & 0 \\
2010 & 0 & 0 \\
\hline
\end{tabular}


Table 4. U.S. EPA aquatic life benchmarks (U.S. EPA, 2012) for prevention of acute and chronic toxicity within freshwater fishes.

\begin{tabular}{lccc}
\hline Pesticide & Class & $\begin{array}{c}\text { Acute Toxicity } \\
(\mu \mathrm{g} / \mathrm{L})\end{array}$ & $\begin{array}{c}\text { Chronic Toxicity } \\
(\mu \mathrm{g} / \mathrm{L})\end{array}$ \\
\hline Atrazine & Herbicide & 2,650 & 65 \\
Atrazine desethyl & $\begin{array}{l}\text { Herbicide } \\
\text { metabolite }\end{array}$ & $2,650^{*}$ & $65^{*}$ \\
Chlorothalonil & Fungicide & 5.3 & 3 \\
Metalaxyl & Fungicide & 65,000 & 9,100 \\
Metolachlor & Herbicide & 1,600 & 1,000 \\
Simazine & Herbicide & 3,200 & 960 \\
\hline
\end{tabular}

* Information not available for fishes therefore acute and chronic concentrations for atrazine were applied.

We measured the concentrations of four herbicides (alachlor, atrazine, metolachlor, simazine), one herbicide metabolite (atrazine desethyl), and two fungicides (chlorothalonil, metalaxyl) from the water samples. Atrazine and its metabolite were selected for measurement because atrazine is the herbicide being targeted by atrazine reduction practices. The other three herbicides were selected because they are commonly detected within agricultural watersheds in the Midwestern United States (Gilliom, 2007). We measured the fungicides because we anticipated they might be emerging contaminants as a result of the concern over soybean rust within our study area. Herbicide and fungicide concentrations were determined by gas chromatography-mass spectroscopy following solid-phase extraction (Zaugg et al. 1995). Samples were vacuum-filtered through 1.6 $\mu \mathrm{m}$ glass fiber filters to obtain $200 \mathrm{~mL}$ aliquots for extraction. Aliquots were fortified with $1 \mathrm{~mL}$ methanol, spiked with $50 \mu \mathrm{L}$ terbuthylazine, and pumped through preconditioned $500 \mathrm{mg}$ $\mathrm{C} 18$ cartridges. Analytes were eluted with ethyl acetate, gently dried under a stream of ultra-high purity nitrogen to approximately $100 \mu \mathrm{L}$ and reconstituted with $1 \mathrm{~mL}$ ethyl acetate containing phenanthrene-d 10 as internal standard. Extracts were stored at $0^{\circ} \mathrm{C}$ until analysis using a coupled gas chromatograph and mass spectrometer. Extraction recovery rates of the seven analytes from the matrix spikes averaged $113 \%$ [minimum $92 \%$ (chlorothalonil) to maximum $145 \%$ (atrazine)]. No analytes were detected in the blank samples from measurements made in 2009 and 2010.

We determined the mean and the maximum seasonal values of atrazine and atrazine desethyl concentrations during each season (spring - March to May; summer - June to August) from each stream from 2005 until 2010. We also calculated the percent occurrence of atrazine and atrazine desethyl during each season throughout this time period. We evaluated the characteristics of the pesticide mixtures by determining the number of pesticides that occur in a water sample, the number of pesticide mixtures that occur, the number of atrazine based mixtures, and the number of simazine based mixtures during each season from each stream from 2006 until 2010. Our evaluation of mixtures only uses data from 2006 and 2010 because we did not have information on two commonly occurring pesticides (i.e., metalaxyl and simazine) in 2005. We also calculated the percent occurrence of each pesticide mixture during each season from each stream. Information on the percent occurrences of the sixteen most commonly occurring pesticide mixtures (i.e., those occurring in $>1 \%$ of all water samples) was used to develop a site by pesticide mixture matrix for our ordination analyses (described below) that were conducted to evaluate the influence of pesticide management on the similarity in the composition of the pesticide mixtures.

We obtained information on the acute and chronic aquatic life benchmarks for fishes (U.S. EPA, 2012) for all measured herbicides and fungicides except for atrazine desethyl (Table 4). These aquatic life benchmarks were developed based on the most sensitive, scientifically acceptable ecotoxicological data for freshwater fishes available to the U.S. EPA (U.S. EPA, 2012). No information is available on toxicological responses of fish to atrazine desethyl and only a limited number of ecotoxicological bioassays have been conducted with invertebrates and plants (Ralston-Hooper et al., 2009). Thus, we followed Graymore et al. (2001) and assumed that the acute and chronic toxicity of atrazine desethyl would be the same as atrazine. We then used our pesticide concentration data to calculate the predicted hazard potential of each water sample using two indexes derived through the concentration addition model (Verro et al., 2009) and the U.S. EPA acute and chronic aquatic life benchmarks for fish (U.S. EPA, 2012). Predicted hazard potential is calculated by the acute hazard index (AHI) and chronic hazard index (CHI) for fishes:

$$
\mathrm{AHI}=\Sigma \mathrm{C}_{\mathrm{i}} / \mathrm{ATS}_{\mathrm{i}} \text { and } \mathrm{CHI}=\Sigma \mathrm{C}_{\mathrm{i}} / \mathrm{CTS}_{\mathrm{i}}
$$

where $C_{i}$ is the concentration of contaminant $i$ in the water sample, ATSi is the acute toxicity aquatic life benchmark for fishes for contaminant $i$, and CTS $_{i}$ is the chronic toxicity aquatic life benchmark for fishes for contaminant i. These indexes are intended to predict the toxicity of pesticide mixtures for fishes knowing the pesticide concentration in the water sample and the pesticide concentration that causes acute toxicity (i.e., mortality within 96 hours) or chronic toxicity (i.e., adverse effects occurring over 28 days or more) to fish in the laboratory. We feel these indexes are useful screening tools because they enable us to go beyond a single pesticide evaluation and to evaluate the water quality relative to established ecotoxicological standards. The advantage of these indexes is that the scores can be interpreted in light of the number of pesticides exceeding the aquatic life benchmarks for fishes. An $\mathrm{AHI}$ and $\mathrm{CHI}$ score of 1 can occur if the concentration of one pesticide in the sample occurs at the aquatic life benchmarks for fishes and all others pesticides are absent. Similarly, the $\mathrm{AHI}$ and $\mathrm{CHI}$ scores will be 6 if the concentrations of six pesticides occur in a mixture at their aquatic life benchmarks. We calculated the mean $\mathrm{AHI}$ and $\mathrm{CHI}$ scores and determined the maximum observed $\mathrm{AHI}$ and $\mathrm{CHI}$ scores during each season from each stream.

\section{Fish Sampling and Community Assessments}

Fish were collected from two sites in each stream in the spring (May to June) and summer (July to August) from 2005 to 2010. We sampled two $125 \mathrm{~m}$ long sites in each stream. One site 
cies richness, abundance, evenness, percent headwater fishes, percent creek chub (Semotilus atromaculatus), percent fathead minnow (Pimephales promelas), percent bluegill (Lepomis macrochirus), trophic guild richness, percent omnivores, percent insectivores, reproductive guild richness, percent guarder-nest spawners, mean length, mean fathead minnow length) for each stream during each sampling period using combined electrofishing and seining data. Species richness is the number of fish species captured and abundance is the number of fishes captured. Evenness is the reciprocal of the Simpson's Index divided by species richness (Smith and Wilson, 1996). The richness and percent of headwater fishes, selected feeding guilds, and reproductive guilds are metrics of the diversity and abundance of fishes with similar habitat requirements, feeding strategies, or reproductive strategies. Fishes were assigned to habitat (i.e., headwater fish species), feeding, and reproductive guilds based on published literature sources (Pflieger, 1975; Becker, 1983; Robison and Buchanan, 1988; Etnier and Starnes, 1993; Ohio EPA, 2002; Ross, 2002; Smiley et al., 2005). Headwater fish species are those fishes expected to be found in first to third order streams in the Midwestern United States, such as creek chub, white suckers (Catosomus commersoni), and orangethroat darters (Etheostoma spectabile) (Ohio EPA, 2002). Omnivores are fishes whose diet consists of plant and animal matter and insectivores are fishes that primarily consume insects and other invertebrates. Guarder-nest spawners are fishes that construct a nest for their eggs and guard the nest and eggs. We also calculated the percentages of each fish species in each stream during each season and then established site by species matrix with the percentages of the ten most abundant fish species for our ordination analyses described below.

\section{Statistical Analyses}

Our experimental design is a reverse $\mathrm{BACl}$ design as we sampled one control stream and one treatment stream during the time period (2005 to 2006 ) that atrazine reduction practices were implemented into the watershed of the treatment stream and the time period (2007 to 2010) that atrazine reduction practices were not implemented in the watershed of the treatment stream. Traditionally, within BACl designs the "before" treatment sampling period occurs in the first part of the study and the "after" occurs in the latter part of the study. Our treatment (i.e., atrazine reduction practices) was implemented via voluntary participation by farmers and producers in the special EQIP and thus we did not have control of when and where atrazine reduction practices were implemented in our treatment watershed. Thus, our BACl design is reversed as the period of 2005 to 2006 corresponds to the traditional "after" period where atrazine reduction practices were implemented in the treatment watershed and the period of 2007 to 2010 corresponds to the traditional "before" period where atrazine reduction practices were not in place in the treatment watershed. The reversal of when the treatment was implemented does not invalidate our experimental design (Clausen and Spooner, 1993; King et al., 2008). Preliminary analyses of data from the first two years of our study also validated the ability of our experimental design to detect an effect of atrazine reduction practices on pesticides and fishes (King et al. 2008).

For all response variables, except pesticide mixture composition and fish species composition, we calculated the difference in each response variable between the control and treatment streams for every sampling period. We then used a two factor analysis of variance (ANOVA) coupled with the Student-Newman-Keuls (SNK) multiple comparison test to determine if the difference in response variables between the control and treatment streams changed as a result of atrazine reduction practices and the interaction of atrazine reduction practices and season. To determine if the similarity in the composition of pesticide mixtures and fish species composition changes we conducted ordination analyses to obtain the site scores that describe the similarity in pesticide mixtures and fish species composition for each stream during each sampling period (Gauch, 1982). We used a Principal Components Analyses (PCA) to obtain the site scores of the first two PCA axes for pesticide mixture composition and a non-metric multidimensional scaling (NMS) to obtain the site scores for the first two NMS axes for fish species composition. We then calculated the Euclidean distance in ordination space between the paired coordinates (i.e., ordination site scores) of the control and treatment stream during each sampling period. A greater Euclidean distance between the control and treatment stream indicates a greater dissimilarity in pesticide mixtures or fish species composition. Conversely, less distance occurring between the control and treatment stream indicates a greater similarity in pesticide mixtures or fish species composition. PCA and NMS analyses were conducted with PC-ORD for Windows (McCune and Mefford 1999). We then used a two factor ANOVA to determine if the similarity in pesticide mixtures and fish species composition between the control and treatment streams changed as a result of atrazine reduction practices and the interaction of atrazine reduction practices and season.

Sixteen (mean atrazine concentration, mean atrazine desethyl concentration, maximum atrazine concentration, maximum atrazine desethyl concentration, percent occurrence of atrazine desethyl, number of pesticide mixtures, number of simazine based mixtures, similarity of pesticide mixtures, mean $\mathrm{AHI}$, mean $\mathrm{CHI}$, maximum $\mathrm{AHI}$, maximum $\mathrm{CHI}$, percent fathead minnow, percent bluegill, trophic guild richness, percent omnivores, and percent guarder-nest spawners) of these 30 response variables did not meet the assumptions of normality and/or equal variance. Therefore, two factor ANOVAs were conducted with rank transformed values for the 16 response variables that did not meet the normality and equal variance assumptions. Rank transformation is commonly recommended in these situations and its use with a parametric test is the equivalent of a nonparametric two factor ANOVA (Conover, 1999). Two factor ANOVAs were conducted with Sigma Stat 3.1 (Systat Software, 2004) and a significance level of $P<0.05$ was used. We only report results on the effects of atrazine reduction practices and the interaction of atrazine reduction practices and season. Selective reporting of our results allows us to focus on the most important results for addressing our hypotheses and enables us to account for the potential influence of season. 
Table 6. Percent occurrence and number of occurrences of pesticide mixtures found within two channelized agricultural headwater streams in the Upper Big Walnut Creek watershed, 2006 to 2010.

\begin{tabular}{|c|c|c|}
\hline Pesticide mixture & $\%$ & \# Samples \\
\hline No pesticides & 15.8 & 80 \\
\hline atrazine-metolachlor & 12.5 & 63 \\
\hline atrazine & 8.3 & 42 \\
\hline atrazine-atrazine desethyl-metolachlor-simazine & 8.3 & 42 \\
\hline atrazine-atrazine desethyl-metolachlor & 7.5 & 38 \\
\hline atrazine-atrazine desethyl-chlorothalonil-simazine & 5.9 & 30 \\
\hline atrazine-atrazine desethyl-chlorothalonil-metalaxyl-metolachlor-simazine & 5.2 & 26 \\
\hline atrazine-metolachlor-simazine & 4.4 & 22 \\
\hline metolachlor & 4.0 & 20 \\
\hline metolachlor-simazine & 3.0 & 15 \\
\hline atrazine-simazine & 2.6 & 13 \\
\hline atrazine-metalaxyl-metolachlor & 2.6 & 13 \\
\hline atrazine-atrazine desethyl-metalaxyl-metolachlor & 2.6 & 13 \\
\hline simazine & 2.0 & 10 \\
\hline atrazine-chlorothalonil-metolachlor-simazine & 1.4 & 7 \\
\hline metalaxyl & 1.2 & 6 \\
\hline atrazine-metalaxyl & 1.0 & 5 \\
\hline atrazine-atrazine desethyl-simazine & 1.0 & 5 \\
\hline atrazine desethyl-metolachlor-simazine & 1.0 & 5 \\
\hline chlorothalonil-metolachlor-simazine & 1.0 & 5 \\
\hline atrazine-metalaxyl-metolachlor-simazine & 1.0 & 5 \\
\hline atrazine-chlorothalonil & 0.8 & 4 \\
\hline atrazine-atrazine desethyl-metalaxyl-metolachlor & 0.8 & 4 \\
\hline atrazine-chlorothalonil-metalaxyl-metolachlor-simazine & 0.8 & 4 \\
\hline chlorothalonil & 0.6 & 3 \\
\hline atrazine-atrazine desethyl & 0.6 & 3 \\
\hline metalaxyl-metolachlor & 0.6 & 3 \\
\hline atrazine-chlorothalonil-metolachlor & 0.6 & 3 \\
\hline chlorothalonil-simazine & 0.4 & 2 \\
\hline metalaxyl-simazine & 0.4 & 2 \\
\hline atrazine-atrazine desethyl-metalaxyl & 0.4 & 2 \\
\hline atrazine-chlorothalonil-simazine & 0.4 & 2 \\
\hline atrazine-metalaxyl-simazine & 0.4 & 2 \\
\hline metalaxyl-metolachlor-simazine & 0.4 & 2 \\
\hline atrazine-chlorothalonil-metalaxyl & 0.2 & 1 \\
\hline atrazine-atrazine desethyl-chlorothalonil-metolachlor & 0.2 & 1 \\
\hline atrazine desethyl-chlorothalonil-metolachlor-simazine & 0.2 & 1 \\
\hline atrazine desethyl-chlorothalonil-metalaxyl-metolachlor-simazine & 0.2 & 1 \\
\hline
\end{tabular}

\section{Results}

We only detected six of seven measured pesticides as alachlor was not detected within any of the water samples (Table 5). Atrazine, metolachlor, and simazine were the three most commonly occurring pesticides within all water samples collected from both streams from 2005 to 2010 (Table 5). These three pesticides also exhibited the greatest mean and maximum concentrations observed during our study (Table 5). The mean number of pesticides detected in a water sample was 2.5 (range 0 to 6 pesticides) and 38 pesticide mixtures were documented from all water samples (Table 6). Our water samples were not dominated by any single pesticide mixture as 31 mixtures oc- curred in $<5 \%$ of all water samples (Table 6 ). The majority of the pesticide mixtures were atrazine or atrazine desethyl based $(71 \%)$ and consisted of two or three pesticides (55\%). The mean $\mathrm{AHI}$ value within all water samples was 0.01 (range 0.00 to 0.37 ) and the mean $\mathrm{CHI}$ value was 0.03 (range 0.00 to 1.29 ). Only three pesticide response variables (difference in mean atrazine desethyl concentration, difference in percent occurrence of atrazine desethyl, and difference in mean number of pesticides within a mixture) differed significantly between the time period with atrazine reduction practices (2005 to 2006) and the time period without atrazine reduction practices (2007 to 2010 ) (Table 7). The mean difference in atrazine desethyl concentration, percent occurrence of atrazine desethyl, and the number 

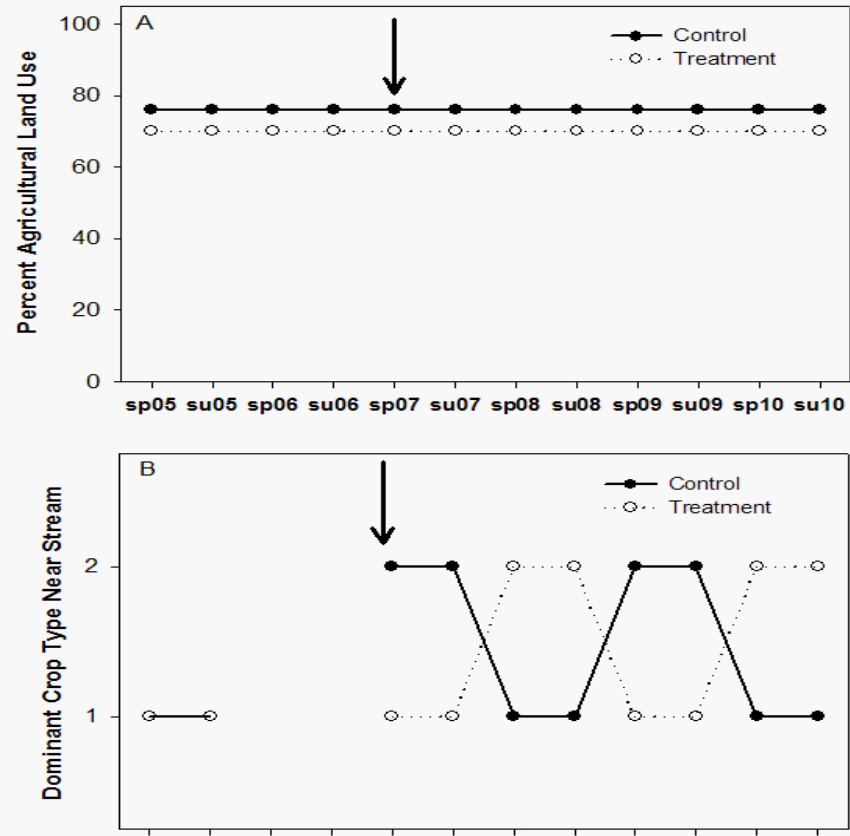

sp05 su05 sp06 su06 sp07 su07 sp08 su08 sp09 su09 sp10 su10

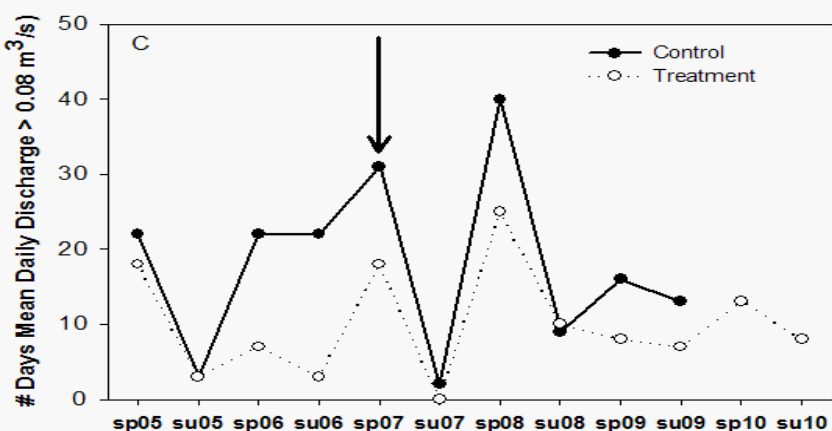

Figure 4. Percent agricultural land use (A), dominant crop type (1 soybean and $2-$ corn) near the stream (B), and number of days discharge $>0.08 \mathrm{~m}^{3} / \mathrm{s}(C)$ within control and treatment streams within the Upper Big Walnut Creek watershed, 2005 to 2010 . Arrows within the figures indicate when atrazine reduction practices were discontinued within the treatment stream. A value of 1 for the dominant crop type near the stream was assigned if the most frequently occurring crop type adjacent (i.e., within $65 \mathrm{~m}$ or less) to the two fish sampling sites in each stream was soybean. A value of 2 was assigned if the most frequently occurring crop type adjacent to the fish sampling sites was corn. The open circles combined with the solid line in 2005 indicate that the dominant crop type for both streams was soybean.

of pesticides between the control and treatment stream was greater during the time period when atrazine reduction practices were applied in the treatment watershed (Figure 2). Notably, atrazine desethyl concentrations and occurrence decreased within the control stream after atrazine reduction practices were discontinued (i.e., the resumption of atrazine application) (Figure 2). Conversely, the number of pesticides increased slightly within the treatment stream after atrazine reduction practices were discontinued (Figure 2). Additionally, the other 12 pesticide response variables were not significantly influenced by atrazine reduction practices or the interaction effect of atrazine reduction
Table 7. $P$ values from two factor ANOVAs conducted to determine if the difference in pesticides and pesticide mixtures between the control and treatment streams was influenced by atrazine reduction practices (AR) and the interaction effect of atrazine reduction practices and season (AR X SE), Upper Big Walnut Creek watershed, Ohio, 2005-2010. Bolded values are significant $(P<0.05)$.

\begin{tabular}{lcc}
\hline Response Variable & AR & AR X SE \\
\hline Atrazine related variables & & \\
Mean atrazine concentration & 0.074 & 0.122 \\
Mean atrazine desethyl concentration & 0.019 & 0.582 \\
Maximum atrazine concentration & 0.070 & 0.139 \\
Maximum atrazine desethyl concentration & 0.066 & 0.340 \\
Percent atrazine occurrence & 0.268 & 0.639 \\
Percent atrazine desethyl occurrence & 0.011 & 0.355 \\
Pesticide mixtures & & \\
Mean number of pesticides within mixture & 0.039 & 0.921 \\
Number of pesticide mixtures & 0.366 & 0.500 \\
Number of atrazine based mixtures & 0.955 & 0.543 \\
Number of simazine based mixtures & 0.793 & 0.442 \\
Similarity in composition of pesticide mixtures & 0.510 & 0.510 \\
Predicted hazard potential of pesticide mixtures for fishes & & \\
Mean Acute Hazard Index & 0.458 & 0.801 \\
Mean Chronic Hazard Index & 0.181 & 0.772 \\
Maximum Acute Hazard Index & 0.816 & 0.746 \\
Maximum Chronic Hazard Index & 0.271 & 0.613 \\
\hline
\end{tabular}

practices and season (Table 7).

We documented 14 fish species from 4608 captures from both study streams during our study (Table 8 ). The five most abundant species captured were fathead minnow (Pimephales promelas), creek chub (Semotilus atromaculatus), bluntnose minnow (Pimephales notatus), Johnny darter (Etheostoma nigrum), and green sunfish (Lepomis cyanellus) (Table 8). Differences in fish species richness, trophic guild richness, and similarity in species composition exhibited significant interaction effects of atrazine reduction practices and season (Table 9). The SNK test did not indicate that significant difference in the mean difference in fish species richness between the control and the treatment streams occurred between time periods with and without atrazine reduction practices during the spring or summer (Figure 3). Conversely, in the spring differences in trophic guild richness and the similarity in fish species composition between the control and treatment streams did not differ between time periods with and without atrazine reduction practices (Figure 3). In the summer the mean difference in trophic guild richness between the control and treatment streams was less when the treatment stream was subjected to atrazine reduction practices and the mean difference increased after atrazine reduction practices were discontinued in the treatment stream (Figure 3. In the summer the mean difference in the distance in NMS ordination space between the control and treatment streams was greater when the treatment stream was subjected to atrazine reduction practices and the mean difference decreased after atrazine reduction practices were discontinued in the treatment stream (Figure 3). No significant effect of atrazine reduction practices 
Table 8. Relative abundance and number of captures of fishes within two channelized headwater streams the Upper Big Walnut Creek watershed, Ohio, 2005 to 2010.

\begin{tabular}{lcc}
\hline Common Name (Scientific Name) & $\%$ & \# Captures \\
\hline Fathead minnow (Pimephales promelas) & 26.2 & 1713 \\
Creek chub (Semotilus atromaculatus) & 13.8 & 906 \\
Bluntnose minnow (Pimephales notatus) & 9.3 & 611 \\
Johnny darter (Etheostoma nigrum) & 7.6 & 496 \\
Green sunfish (Lepomis cyanellus) & 3.9 & 255 \\
Orangethroat darter (Etheostoma spectabile) & 2.7 & 179 \\
Bluegill (Lepomis macrochirus) & 2.4 & 157 \\
White sucker (Catostomus commersoni) & 1.9 & 126 \\
Largemouth bass (Micropterus salmoides) & 1.3 & 86 \\
Central stoneroller (Campostoma anomalum) & 1.1 & 70 \\
Yellow bullhead (Ameiurus natalis) & $<1.0$ & 6 \\
Channel catfish (Ictalurus punctatus) & $<1.0$ & 1 \\
Fantail darter (Etheostoma flabellare) & $<1.0$ & 1 \\
Golden shiner (Notemigonus crysoleucas) & $<1.0$ & 1 \\
\hline
\end{tabular}

or the interaction effect of atrazine reduction practices and season was observed for the remaining 12 fish community response variables (Table 9).

\section{Discussion}

Our results do not support our hypotheses that atrazine reduction practices reduce atrazine and atrazine desethyl concentrations and occurrence or alter the pesticide mixtures and their predicted toxicity on fishes within channelized agricultural headwater streams in the spring and summer. Only three (atrazine desethyl concentration, atrazine desethyl percent occurrence, and number of pesticides) of fifteen pesticide response variables indicated a potential effect of atrazine reduction practices However, two of these pesticide response variables (atrazine desethyl concentration, atrazine desethyl occurrence) did not increase as expected within the treatment stream after discontinuation of atrazine reduction practices in the watershed, but instead decreased within the control stream.

The observed trends in percent agricultural land use did not change in either watershed before or after implementation of atrazine reduction practices (Figure 4). The dominant crop type near the stream exhibited the expected corn-soybean crop rotations that occurs in many agricultural fields in the Midwestern United States (Figure 4). However, atrazine and atrazine desethyl concentrations between streams before and after implementation of atrazine reduction practices did not correspond with the observed pattern of crop rotations. Trends in the number of days above the six year mean discharge value $\left(0.08 \mathrm{~m}^{3} / \mathrm{sec}\right)$ before and after implementation of atrazine reduction practices were similar between our study streams and suggested our results were not influenced by hydrological differences (Figure 4). Information on the implementation of other conservation practices is not publicly available, but our qualitative observations suggest the amounts of observable conservation practices (i.e., grass filter strips, grassed waterways, tillage
Table 9. $P$ values from two factor ANOVAs conducted to determine if the difference in fish community response variables between the control and treatment streams was influenced by atrazine reduction practices (AR) and the interaction effect of atrazine reduction practices and season (AR X SE), Upper Big Walnut Creek watershed, Ohio, 2005-2010. Bolded values are significant $(P<0.05)$.

\begin{tabular}{lcc}
\hline Response Variable & AR & AR X SE \\
\hline Fish species richness & 0.653 & $\mathbf{0 . 0 4 8}$ \\
Abundance & 0.904 & 0.384 \\
Evenness & 0.178 & 0.688 \\
Percent Headwater Fishes & 0.397 & 0.945 \\
Percent Creek Chub & 0.861 & 0.692 \\
Percent Fathead Minnow & 1.00 & 1.00 \\
Percent Bluegill & 0.303 & 0.959 \\
Trophic Guild Richness & 0.180 & $\mathbf{0 . 0 2 4}$ \\
Percent Omnivores & 0.240 & 0.953 \\
Percent Insectivores & 0.063 & 0.180 \\
Reproductive Guild Richness & 0.242 & 0.130 \\
Percent Guarder-Nest Spawners & 0.350 & 0.112 \\
Mean Length (All species) & 0.267 & 0.267 \\
Mean Fathead Minnow Length & 0.917 & 0.532 \\
Similarity in Species Composition & $\mathbf{0 . 0 4 1}$ & $\mathbf{0 . 0 2 9}$ \\
\hline
\end{tabular}

practices) within the watersheds were similar between streams. Soil characteristics, such as soil type, organic matter content, $\mathrm{pH}$, influence pesticide transport throughout agricultural watersheds (Jenks et al., 1998; Coquet, 2002), but soil types, bulk density, water holding capacity, and total carbon were similar between our study streams.

We do not believe that differences in precipitation or air temperature between streams influenced the observed results because of the close proximity of both streams to each other. Perhaps it is a combination of the timing of pesticide application and the amount and timing of spring rainfall events that influences atrazine concentrations within both streams after atrazine reduction practices were discontinued. Instream atrazine concentrations typically increase during storm events after atrazine application because of a flushing effect that mobilizes and transports atrazine and other contaminants to the streams via surface runoff and through the soil (Thurman et al., 1991; Hyer et al., 2001). Herbicides with longer half lives, such as atrazine or simazine, exhibit elevated storm event concentrations for longer periods after application than herbicides with shorter half lives (Matthiessen et al., 1992; Williams et al., 1995). Lerch et al. (2011 b) found the greatest annual atrazine losses when planting of corn (i.e., a surrogate for atrazine application timing and extent) was completed on the majority the cropland in a Missouri watershed was immediately followed by a series of runoff events (i.e., precipitation events) that transported $95 \%$ of the annual atrazine load. Conversely, the least annual atrazine losses within this watershed occurred in years when only one small runoff event occurred 26 days after corn planting (i.e., atrazine application) was completed (Lerch et al., $2011 \mathrm{~b}$ ). In our study 2008 and 2009 represented two years with different spring maximum atrazine concentrations, precipitation, discharge, and possible timing of pesticide application scenarios. 
The spring 2008 maximum values of atrazine (A - $50.3 \mu \mathrm{g} / \mathrm{L}$, $\mathrm{B}-82.5 \mu \mathrm{g} / \mathrm{L} / \mathrm{L}$ ) occurred on the $5 / 12 / 2008$. From $5 / 10$ to $5 / 12 / 2008$ mean total precipitation was $11.9 \mathrm{~mm}$ and mean daily discharge was six times greater $\left(0.49 \mathrm{~m}^{3} / \mathrm{s}\right)$ than our six year mean discharge value. Corn planting progress was half complete in Ohio by $5 / 11 / 2008$. The spring 2009 maximum values of atrazine (A $-0.5 \mu \mathrm{g} / \mathrm{L}, \mathrm{B}-0.3 \mu \mathrm{g} / \mathrm{L}$ ) occurred on $5 / 18 / 2009$. From $5 / 16$ to $5 / 18 / 2009$ mean total precipitation was $0.9 \mathrm{~mm}$ and mean daily discharge was less $\left(0.03 \mathrm{~m}^{3} / \mathrm{s}\right)$ than our six year mean discharge value. Corn planting progress was only $39 \%$ complete in Ohio by $5 / 18 / 2009$. Thus, in both streams maximum spring atrazine concentrations after atrazine reduction practices were discontinued were less during periods of reduced discharge and delayed corn planting progress (i.e., atrazine application) and were greater during periods of increased discharge and corn planting progress (i.e., atrazine application) was half completed. These observations are supportive of the potential effect of a combination of the timing of pesticide application and the amount and timing of spring rainfall events on our results.

We also only observed a potential effect of atrazine reduction practices on two of fifteen fish community response variables. However, we concluded our fish community results did not support our hypothesis that atrazine reduction practices would alter fish communities because we did not observe an effect of atrazine reduction practices on the predicted causal mechanisms (i.e., concentration and occurrence of atrazine and atrazine desethyl, pesticide mixtures, or the predicted toxicity of pesticide mixtures) that would have enabled atrazine reduction practices to alter fish communities.

Our results are consistent with others who conducted long term research projects to determine the influence of pesticide reduction practices and other types of conservation practices on pesticide concentrations within agricultural streams in the Midwestern United States. Concentrations of alachlor, atrazine, chlorothalonil, metalaxyl, metolachlor, and simazine did not differ between channelized agricultural headwater streams with and without grass filter strips in central Ohio (Smiley et al., 2011). Modification of $19 \%$ of the watershed land use within an lowa stream by converting agricultural fields to prairie, adopting no-till tillage, and eliminating pre-emergence herbicide application did not reduce atrazine concentrations and occurrence (Schilling and Thompson, 2000). Implementation of grassed waterways, terraces, removal of cropland via the Conservation Reserve Program, and vegetative buffers over a 15 year period within 15\% of a Missouri watershed did not result in decreases to alachlor, atrazine, acetochlor, metolachlor, and metribuzin concentrations (Lerch et al., 2011 a, Lerch et al., 2011 b).

The limited effectiveness of pesticide reduction practices and other conservation practices in reducing pesticide concentrations in our study and others (Schilling and Thompson, 2000; Lerch et al., 2011 a; Lerch et al., 2011 b) might be a result of the limited amounts of the watershed modified as the amount of watersheds modified only ranged from $15 \%$ to $30 \%$. Conversely, other studies that examined long term trends between pesticide usage and pesticide concentrations observed decreases in concentrations of pesticides that are discontinued from use (i.e., alachlor) and in- creases in concentrations of pesticides that are newly introduced to the market (i.e., acetochlor) (Scribner et al., 2000; Vecchia et al., 2009). In these studies pesticide usage trends were reported as amount of pesticides applied rather than as the percentages of the watershed area receiving pesticide application. It is assumed that changes in pesticide usage occurred over large spatial areas and encompassed the majority of the watershed area, but these previous studies (Scribner et al., 2000; Vecchia et al., 2009) did not provide this information. The conclusions that can be derived from these large scale studies (Scribner et al., 2000; Vecchia et al., 2009) are limited, but these studies do suggest that implementation of pesticide reduction practices in the majority of a watershed is needed to decrease in pesticide concentrations within the streams at the watershed scale. Future field research is critically needed to determine the exact percentages of watershed manipulation required to achieve pesticide concentration reductions.

The inability of grass filter strips to reduce herbicide and fungicide concentrations within agricultural headwater streams in central Ohio was attributed to the presence of tile-drains that enable agricultural runoff to bypass the grass filter strips (Smiley et al., 2011). The watersheds in our study are also tiledrained, but we do not feel that this is an influencing factor on our results because it is not possible for tile-drains to alter the effectiveness of atrazine reduction practices such as usage of different pesticides or reduced atrazine application rates.

Our results and others (Lerch et al., 2011 a; Lerch et al., 2011 b; Smiley et al., 2011) may have been influenced by the locations within the watershed where pesticide reduction practices and other conservation practices were implemented. We were not able to obtain information on the exact locations of atrazine reduction practices and other conservation practices within our study sites because this information is not available for privately-owned lands due to federal privacy regulations and bureaucracy. Increasing proximity of insecticide application to sampling sites resulted in increased insecticide concentrations within a California stream (Hunt et al., 2006). Additionally, small-scale hydrological characteristics within a watershed can create hotspots capable of facilitating the transport of pesticides into adjacent streams (Freitas et al., 2008). These findings suggest that where pesticide reduction practices are applied within agricultural watersheds might be a critical determinant as to its effectiveness. In our study it is also possible the landowners within the watershed of the treatment stream may have chosen to implement the lesser effective atrazine reduction practices (i.e., reduced rate atrazine application) instead of those practices that completely eliminate atrazine usage (i.e., use of alternative herbicide or planting a small grain). Unfortunately, this information is not available to us either, but we suspect the more effective practices were most likely selected because farmers received the greatest compensation for these practices and they were most popular selection across the larger UBWC watershed.

\section{Conclusions}

Our results and others (Schilling and Thompson, 2000; Lerch et al., 2011 a; Lerch et al., 2011 b) from small watersheds (< 80 
$\mathrm{km}^{2}$ watershed area) in the Midwestern United States suggest that implementation of pesticide management strategies aimed at reducing atrazine usage or the implementation of conservation practices within small portions ( $30 \%$ or less) of small agricultural watersheds will not be effective in reducing pesticide concentrations within agricultural streams. Our results also suggest that pesticide reduction practices that do not lead to reductions in target pesticides are not likely to influence fish communities within channelized agricultural headwater streams. Our results and those of others (Schilling and Thompson, 2000; Lerch et al., $2011 \mathrm{a}$; Lerch et al., $2011 \mathrm{~b}$ ) suggest the following watershed management strategies may assist with reducing pesticide concentrations within channelized agricultural headwater streams:

1. Pesticide reduction practices implemented for the conservation and restoration of these small agricultural watersheds should be implemented on the majority of agricultural land use within watershed. Particularly, in our study atrazine reduction practices for reducing atrazine usage was limited to cropland planted with corn. Implementation of pesticide reduction practices targeted to reduce usage of other pesticides on cropland with soybean or wheat may assist with further reducing the number of pesticides occurring within the streams.

2. The probable influence of the combination of the timing of pesticide application and occurrence of rainfall event suggests that the use of pest management practices that involve monitoring the weather and not applying pesticides just prior to rainfall events in conjunction with pesticide reduction practices may be an effective way of preventing excessive pesticide concentrations from occurring in these small streams.

Field research on the effectiveness of pesticide reduction practices on pesticides and fishes in agricultural streams is lacking and more research is critically needed to develop effective conservation and restoration strategies for agricultural streams.

\section{Acknowledgements}

We thank C. Lenhart and R. Lizzotte for helpful comments on an earlier version of this manuscript. S. Hess, A. Kemble, A. Rapp, G. Roberts, J. Risley, and R. Shaw assisted with field work. E. Fischer provided information on methods and $Q A / Q C$ procedures for pesticide measurements. We also thank the other numerous past and current USDA-ARS Soil Drainage Research Unit personnel for their assistance with laboratory work and logistical support. D. Shields Jr., S. Knight, and L. Williams provided constructive feedback on the initial sampling design. B. Bacon provided information on watershed characteristics. Landowner and site information were provided by Soil and Water Conservation and NRCS districts in Delaware and Morrow counties. We also are grateful to the landowners who provided access to the sites.

\section{References}

Becker GC (1983) Fishes of Wisconsin. University of Wisconsin Press, Madison, WI, USA.

Brian R (1995) Weed killers by the glass. Environmental Working Group. Washington, DC, USA.

Clausen JC and J Spooner (1993) Paired watershed study design. Report 841-F-93-009. United States Environmental Protection Agency, Office of Water, Washington, DC, USA.

Conover WJ (1999) Practical nonparametric statistics. Wiley, New York, NY, USA.

Coupe RH and JD Blomquist (2004) Water-soluble pesticides in finished water of community water supplies. J Am Water Works Assoc 96: 56-68.

Coquet $Y$ (2002) Variation in pesticide sorption isotherm in soil at catchment scale. Pest Manag Sci 58: 69-78.

Crawford CG (2001) Factors affecting pesticide occurrence and transport in a large Midwestern River basin. J Am Water Resour Assoc 37: 1-15.

Dabrowski JM, SKC Peall, A Van Niekerk, AJ Reinecke, JA Day, and R Shulz (2002) Predicting runoff-induced pesticide input in agricultural sub-catchment surface waters: linking catchment variables and contamination. Water Res 36: 4975-4984.

Etnier DA and WC Starnes (1993) The fishes of Tennessee. University of Tennessee, Knoxville, TN, USA.

Freitas LG, H Singer, SR Muller, RP Schwarzenbach, and C Stamm (2008) Source area effects on herbicide losses to surface waters - a case study in the Swiss Plateau. Agric Ecosyst Environ 128: 177-184.

Gauch HG, Jr. (1982) Multivariate analysis in community ecology. Cambridge University Press, Cambridge, UK.

Gilliom RJ (2007) Pesticides in U. S. streams and groundwater. Environ Sci Technol 41 : 3409-3414.

Graymore M, F Stagnitti, and G Allinson (2001) Impacts of atrazine in aquatic ecosystems. Environ Int 26: 483-495.

Green RH (1979) Sampling Design and statistical methods for environmental biologists. John Wiley and Sons, New York, NY. USA.

Hammond CM, EC Luschei, CM Boerboom, and PJ Nowak (2006) Adoption of integrated pest management tactics by Wisconsin farmers. Weed Technol 20: 756-767.

Homes MJ, JR Frankenberger, and BA Engel (2001). Susceptibility of Indiana watersheds to herbicide contamination. J Am Water Resour Assoc 37: 987-1000.

Hunt J, B Anderson, B Phillips, R Tjeerdema, N Richard, V Connor, K Worcester, M Angelo, A Bern, B Fulfrost, and D Mulvaney (2006) Spatial relationships between water quality and pesticide application rates in agricultural watersheds. Environ Monit Assess 121: 245-262.

Hyer KE, GM Hornberger, and JS Herman (2001) Processes controlling the episodic streamwater transport of atrazine and other agrichemicals in an agricultural watershed. J Hydrol 254: 47-66.

Jaynes DB, JL Hatfield, and DW Meek (1999) Water quality in Walnut Creek watershed: herbicides and nitrate in surface waters. J Environ Qual 28: 45-59.

Jenks BM, FW Roeth, AR Martin, and DL McCallister (1998) Influence of surface and subsurface soil properties on atrazine sorption and degradation. Weed Sci 46: 132-138.

Karr JR (1999) Defining and measuring river health. Freshwater Biol 41: 221-234.

Kay P, AC Edwards, and M Foulger (2009) A review of the efficacy of contemporary agricultural stewardship measures for ameliorating water pollution problems of key concern to the UK water industry. Agric Systems 99: 67-75.

Kerr J and K Chung (2001) Evaluating watershed management projects. Water Policy 3: 537-554.

King KW, PC Smiley Jr., BJ Baker, and NR Fausey (2008) Validation of 
paired watersheds for assessing conservation practices in Upper Big Walnut Creek watershed, Ohio. J Soil Water Cons 63: 380-395.

Kogan M (1998) Integrated pest management: historical perspectives and contemporary developments. Annu Rev Entomol 43: 243-270.

Kreuger J (1998) Pesticides in stream water within an agricultural catchment in southern Sweden, 1990-1996. Sci Total Environ 216: 227-251.

Lerch RN and PE Blanchard (2003) Watershed vulnerability to herbicide transport in northern Missouri and Southern lowa streams. Environ Sci Technol 37: 5518-5527.

Lerch RN, EJ Sadler, C Baffaut, NR Kitchen, and KA Sudduth (2011 a) Herbicide transport in Goodwater Creek Experimental Watershed: I: long-term research on acetochlor, alachlor, metolachlor, and metribuzin. J Am Water Resour Assoc 47: 224-238.

Lerch RN, EJ Sadler, KA Sudduth, C Baffaut, and NR Kitchen (201 1 b) Herbicide transport in Goodwater Creek Experimental Watershed: I: long-term research on atrazine. J Am Water Resour Assoc 47: 209-223.

Malcom Pirnie, Inc. (1999) Upper Big Walnut Creek watershed water quality management plan. Columbus, $\mathrm{OH}$, USA.

Maltby L and L Hills (2008) Spray drift of pesticides and stream macroinvertebrates: experimental evidence of impacts and effectiveness of mitigation measures. Environ Pollut 156: $1112-1120$.

Matthiessen P, C Allchin, RJ Williams, SC Bird, D Brooke, and PJ Glendinning (1992) The translocation of some herbicides between soil and water in a small catchment. Water Environ J 6: 496-504.

McCune B and MJ Mefford (1999) Multivariate analysis of ecological data version 4.01. MiM software, Gleneden Beach, OR, USA.

NRCS (2010) Integrated pest management (code 595) conservation practice standard. USDA Natural Resources Conservation Service, Washington, DC, USA.

Ohio EPA (2002) Field evaluation manual for Ohio's primary headwater habitat streams. Ohio Environmental Protection Agency, Division of Surface Water, Columbus, OH, USA.

Ohio EPA (2005) Total maximum daily loads for the Big Walnut Creek watershed. Final Report, State of Ohio Environmental Protection Agency, Division of Surface Water, Columbus, $\mathrm{OH}$, USA.

Ohio EPA (2008) Ohio 2008 integrated water quality monitoring and assessment report. Division of Surface Water, Ohio EPA, Columbus, $\mathrm{OH}$, USA.

Ohio EPA (2010) Ohio 2010 integrated water quality monitoring and assessment report. Ohio Environmental Protection Agency, Division of Surface Water, Columbus, OH, USA.

Pflieger WL (1975) The fishes of Missouri. Missouri Department of Conservation, Jefferson City, MO, USA.

Ralston-Hooper KR, J Hardy, L Hahn, H Ochoa-Acuna, LS Lee, R Mollenhaver, and MS Sepulveda (2009) Acute and chronic toxicity of atrazine and its metabolites deethylatrazine and deisopropylatrazine on aquatic organisms. Ecotoxicology 18: 899-905.

Reichenberger S, M Bach, A Skitschak, and H Frede (2007) Mitigation strategies to reduce pesticide inputs into ground- and surface water and their effectiveness: a review. Sci Total Environ 284: 1-35.

Robison HW and TM Buchanan (1988) Fishes of Arkansas. The University of Arkansas Press, Fayetteville, AR, USA.

Ross ST (2002) The inland fishes of Mississippi. University Press of Mississippi, Jackson, MS, USA.

Schilling KE and CA Thompson (2000) Walnut Creek watershed moni- toring project, lowa: monitoring water quality in response to prairie restoration. J Am Water Resour Assoc 36: 1101-1114.

Scribner EA, WA Battaglin, DA Goolsby, and EM Thurman (2000) Changes in herbicide concentrations in Midwestern streams in relation to changes in use, 1989-1998. Sci Total Environ 248: 255-263.

Smiley Jr. PC, ED Dibble, and SH Schoenholtz (2005) Fishes of first-order streams in north-central Mississippi. Southeast Nat 4: 219-236.

Smiley Jr. PC and RB Gillespie (2010) Influence of physical habitat and agricultural contaminants on fishes within agricultural drainage ditches. In: MT Moore, R Kroger (eds.) Agricultural drainage ditches: mitigation wetlands for the 21 st century, Research Signpost, Kerula, India, pp. 37-73.

Smiley Jr. PC, FD Shields Jr., and SS Knight (2009) Designing impact assessments for evaluating the ecological effects of agricultural conservation practices on streams. J Am Water Resour Assoc 45: 867-878.

Smiley Jr. PC, KW King, and NR Fausey (2010) Public health perspectives of channelized and unchannelized headwater streams in central Ohio: a case study. J Water Health 8: 577-592.

Smiley Jr. PC, KW King, and NR Fausey (2011) Influence of herbaceous riparian buffers on physical habitat, water chemistry, and stream communities within channelized agricultural headwater streams. Ecol Eng 37: 1314-1323.

Smith B and JB Wilson (1996) A consumer's guide to evenness indices. Oikos 76: 70-82.

Systat Software (2004) SigmaStat for Windows Version 3.11. San Jose, CA, USA.

Thurman EM, DA Goolsby, MT Meyer, and DW Kolpin (1991) Herbicides in surface waters of the midwestern United States: the effect of spring flush. Environ Sci Tech 25: 1794-1796.

USDA NASS (2000) Pest management practices 1999 summary report. USDA National Agricultural Statistics Service, Washington, DC, USA.

US EPA (2012) Office of Pesticide Program's aquatic life benchmarks. U.S. Environmental Protection Agency webpage. Available online at http://www.epa.gov/oppefed 1 /ecorisk_ders/aquatic_life_benchmark.htm. Accessed 21 February 2012.

Vecchia AV, RJ Gilliom, DJ Sullivan, DL Lorenz, and JD Martin (2009) Trends in concentrations and use of agricultural herbicides for corn belt rivers, 1996-2006. Environ Sci Technol 43: 9096-9102.

Verro RT, A Finizio, S Otto, and M Vighi (2009) Predicting pesticide environmental risk in intensive agricultural areas. II: Screening level risk assessment of complex mixtures in surface waters. Environ Sci Technol 43: 530-537.

Vu SH, S Ishihara, and H Watanabe (2006) Exposure risk assessment and evaluation of the best management practice for controlling pesticide runoff from paddy fields. Part 1: paddy watershed monitoring. Pest Manag Sci 62: 1193-1206.

Williams RJ, DN Brooke, P Matthiessen, M Mills, A Turnbull, and RM Harrison (1995) Pesticide transport to surface waters within an agricultural catchment. Water Environ J 9: 72-81.

Zaugg SD, MW Sandstrom, SG Smith, and KM Fehlberg (1995) Methods of analysis by the U.S. Geological Survey National Water Quality Laboratory-determination of pesticides in water by C-18 solid-phase extraction and capillary-column gas chromatography/ mass spectrometry with selected-ion monitoring. Open-File Report 95-181, U.S. Geological Survey, Denver, CO. 